\title{
Effect of single dose follicle stimulating hormone on follicular aspiration, in vitro fertilization and pregnancy rate
}

\section{Efeito do hormônio folículo estimulante em dose única na aspiração folicular, fertilização in vitro e taxa de prenhez}

\author{
Mayara Ellen Bardi de Moraes ${ }^{1}$; Paulo Roberto Adona ${ }^{1}$ (D); Samuel Guemra ${ }^{1}$; \\ Tiago Henrique Camara de Bem²; Moysés dos Santos Miranda ${ }^{3}$ \\ ${ }^{1}$ Universidade Norte do Paraná, Curso de Medicina Veterinária, Arapongas - PR, Brazil \\ ${ }^{2}$ Universidade de São Paulo, Faculdade de Zootecnia e Engenharia de Alimentos, Departamento de Medicina Veterinária, Pirassununga - SP, \\ Brazil \\ ${ }^{3}$ Universidade Federal do Pará, Faculdade de Medicina Veterinária, LabTronVet, Castanhal - PA, Brazil
}

\begin{abstract}
The present study evaluated Brangus cows treated with single doses of follicle stimulating hormone (FSH) subjected to follicular aspiration after $24 \mathrm{~h}$ to assess oocyte recovery, in vitro fertilization and pregnancy rate. Follicles exceeding 3 millimeters in diameter were aspirated, $200 \mathrm{mg}$ of FSH was administered 2 days later, and a new ovum pickup was performed $24 \mathrm{~h}$ afterward. These methods were performed 3 times every 3 days. In control, follicular aspirations occurred at intervals of 1-week without FSH administration o. The aspirated oocytes were evaluated, submitted to in vitro fertilization and the embryos were transferred to the recipients. The average recovery of oocytes was higher $(\mathrm{p}<0.05)$ in control cows $(12.4 \pm 1.8)$ than in treated cows $(9.4 \pm 1.3)$. There was no difference $(\mathrm{p}>0.05)$ in the mean percentage of viable oocytes (52.0 \pm 3.9 and $62.7 \pm 4.7 \%)$ or the mean percentage of embryos $(41.4 \pm 4.8$ and $41.5 \pm 4.2 \%)$ among control and treated cows, respectively. The mean percentage of pregnancy did not differ ( $\mathrm{p}>0.05)$ for control cows $(43.8 \pm 2.7 \%)$, and treated cows $(40.9 \pm 6.8 \%)$. In conclusion, FSH treatment did not improve oocyte recovery, in vitro fertilization, and pregnancy percentage. However, there is possibility of several consecutive ovum pickup every t3 days, concentrating the in vitro fertilization and the pregnancy percentage.
\end{abstract}

Keywords: Bovine. Follicle. Ovum pickup.

\section{RESUMO}

O presente estudo avaliou vacas Brangus tratadas com doses únicas de hormônio folículo estimulante (FSH) submetidas a aspiração folicular após vinte e quatro horas, para avaliação da recuperação oocitária, fertilização in vitro e taxa de prenhez. Folículos superiores a três milímetros de diâmetro foram aspirados, $200 \mathrm{mg}$ de FSH foram administrados dois dias depois e uma nova aspiração folicular foi realizada 24 horas após. Esses métodos foram efetivados três vezes a cada três dias. No controle, as aspirações foliculares ocorreram em intervalos de uma semana sem administração de FSH. Os oócitos aspirados foram avaliados, submetidos à fertilização in vitro e os embriões foram transferidos em receptoras. A recuperação média dos oócitos foi superior $(\mathrm{p}<0,05)$ nas vacas controle $(12,4 \pm 1,8)$ do que nas vacas tratadas $(9,4 \pm 1,3)$. Não houve diferença $(\mathrm{p}>0,05)$ na porcentagem média de oócitos viáveis $(52,0 \pm 3,9$ e $62,7 \pm 4,7 \%)$ ou na porcentagem média de embriões $(41,4 \pm 4,8$ e $41,5 \pm 4,2 \%)$ entre vacas controle e vacas tratadas, respectivamente. A porcentagem média de prenhez não diferiu $(\mathrm{p}>0,05)$ para as vacas controle $(43,8 \pm 2,7 \%)$ e as tratadas $(40,9 \pm 6,8 \%)$. Em conclusão, o tratamento com FSH não melhorou a recuperação de oócitos, a fertilização in vitro e o percentual de prenhez. No entanto, existe a possibilidade de várias aspirações foliculares consecutivas a cada três dias, concentrando a fertilização in vitro e o percentual de prenhez.

Palavras-chave: Aspiração follicular. Bovinos. Folículos. 
Correspondence to:

Paulo Roberto Adona

Universidade Norte do Paraná, Curso de Medicina Veterinária.

Av. Gaturamo, Rodovia PR 218

CEP: 86702-670, Arapongas - PR, Brasil

e-mail: paulo_adona@yahoo.com.br

Received: April 16, 2019

Approved: August 28, 2019

How to cite: Moraes MEB, Adona PR, Guemra S, De Bem THC, Miranda MS. Effect of single dose follicle stimulating hormone on follicular aspiration, in vitro fertilization and pregnancy rate. Braz J Vet Res Anim Sci. 2019;56(3):e156894. https://doi.org/10.11606/issn.16784456.bjvras.2019.156894

\section{Introduction}

The recovery of oocytes via follicular aspiration associated with in vitro fertilization is a biotechnique used to accelerate the production of animals with superior characteristics. Embryos produced in vitro correspond to more than $40 \%$ of the embryos produced in the world (Monteiro et al., 2017; Perry, 2014). This interest in the in vitro fertilization is due to several factors, such as improvements in the in vitro culture system, acceleration of the production of animals with superior characteristics, and the possibility of using sexed semen, enabling the production of livestock of a defined sex (Gimenes et al., 2015; Monteiro et al., 2017; Pontes et al., 2010).

Despite advances in in vitro fertilization, several factors may still limit the achievement of success of this biotechnology, such as: variations in the number of ovarian follicles between animals or breeds (Bos indicus and Bos taurus), and the management techniques for in vivo production of embryos (Baruselli et al., 2007; Gimenes et al., 2015; Monteiro et al., 2017; Pontes et al., 2010). There is still no conclusive biological explanation to explain the variability between animals in the amount of oocytes aspirated via ovum pickup (OPU) (Pontes et al., 2010). However, due to the advances in in vitro fertilization, there is an increasing interest in races, until now little explored in the use of biotechniques (Guemra et al., 2014). The enhancement of hormonal treatment that promotes ovarian stimulation adjusted to support follicular development may allow collection of a more significant number of oocytes per animal, optimizing the production of embryos in vitro (Pontes et al., 2010; Vieira et al., 2014). This allows a substantial development in the production of composite breeds used for dairy or cutting, considering their adaptability and productivity (Guemra et al., 2014; Pontes et al., 2010; Vieira et al., 2014). Controlling the plasma concentration of follicle stimulating hormone (FSH) may be an option to elevate oocyte recovery in different pure or synthetic races.

Follicular development is related to the transient increase of serum FSH that promotes the emergence of small follicles (Gupta et al., 2014). However, the decreasing concentration of serum FSH disrupts the development of the subordinate follicles that enter atresia and interrupts the selection of new subordinate follicles. A single follicle continues development (growth) to ovulatory size with an increase in the amount of estradiol synthesis, since the subordinate follicles lose the ability to synthesize estradiol and die from follicular atresia (Adams et al., 2008; Gupta et al., 2014; Nasser et al., 1993).

A strategy to increase oocyte recovery by OPU may be via the application of exogenous FSH in oocyte donors. This transient increase in serum FSH may delay the advance of the dominant follicle, atresia of the other follicles (subordinate), and increased size of the ovarian follicles making them accessible to OPU (Ginther et al., 2017; Mihm et al., 1997). However, this transient increase in exogenous FSH may be influenced by a number of factors, ranging from changes in the administered concentration to the frequency of administration, and the interactions with the luteinizing hormone (LH) (Kelly et al., 1997). Another critical factor that must be considered concerns the reproductive peculiarities of the Bos indicus and Bos taurus breeds (Baruselli et al., 2007).

Crossing between animals Bos taurus and Bos indicus is a strategy used to improve productivity and rusticity of animals in subtropical areas (Lamy et al., 2012). These crosses in cattle generally outperform the pure parental breeds in subtropical conditions due to heterosis (Burrow, 2015). The Brangus breed, originating from the genetics of Angus animals crossed with Zebu, produces more rustic animals with good adaptability and fertility, and may be an option for subtropical areas. Despite their value, there are few studies in the literature about the use of assisted reproductive biotechniques using Brangus cows. In this context, the present study aimed to evaluate Brangus cows, treated with FSH in single doses and follicular aspiration $24 \mathrm{~h}$ after FSH treatment, with new doses every 3 days, to determine the number of oocytes aspirated, in vitro fertilization and rate of pregnancy. 


\section{Material and Methods}

\section{Selection of donor cows}

Twelve Brangus cows (5/8 Nellore and 3/8 Angus) were selected (estrous cycle) in the follicle development phase, containing more than 10 follicles in the ovaries ( $>3 \mathrm{~mm}$ diameters) and with a body score equal to or greater than 3 (scale 1-5). The cows were organized in groups (treated with FSH and control without FSH) with a similar follicular population and kept in Brachiaria brizantha grass, with availability to water and mineral salt ad libitum.

\section{OPU from donors}

At day zero (Day 0), ovaries with follicles greater than $3 \mathrm{~mm}$ in diameter were aspirated to start the study. After $48 \mathrm{~h}$ (day 2) in the FSH-treated cow group, a single $200 \mathrm{mg}$ dose of FSH (Folltropin-V, Bioniche Animal Health USA, Inc.) was applied intramuscularly and $24 \mathrm{~h}$ later (Day 3 ), a new OPU was performed. Three consecutive treatments were performed every 3 days (Figure 1). In cows without hormonal treatments, follicular aspirations are usually performed at intervals of 1 week or more. However, follicular aspiration performed more than once per week significantly reduces the number of oocytes recovered. According to this explanation, untreated cows (control) were submitted to OPU once a week. A convex transducer (5-12 MHz) coupled to the DP-2200Vet ultrasound (Mindray Medical International Ltd., China) was used to perform the OPU according to Guemra et al. (2014).

\section{Selection of oocytes aspirated}

Most chemical items were purchased from Sigma-Aldrich, Inc. (St. Louis, MO, USA), unless otherwise specified. After each OPU, the oocytes were selected and counted using a filter and a gridded search dish all-in-one (Bioniche Animal Health Canada, ECE051) and a stereomicroscope (Nikon Instruments Inc., USA, SMZ1000). Only oocytes classified as viable (one or more layers of cumulus cells and homogeneous cytoplasm) were sent for in vitro fertilization (laboratory) in $1.5 \mathrm{~mL}$ tubes (Corning Incorporated, USA, 430487) with $1 \mathrm{~mL} \mathrm{H199}$ (Sigma, M7528) with 10\% FBS, $50 \mu \mathrm{g} / \mathrm{mL}$ gentamycin, $100 \mu \mathrm{M}$ cysteamine and $0.2 \mu \mathrm{M}$ pyruvate (Guemra et al., 2014).

\section{In vitro maturation}

After approximately $4 \mathrm{~h}$ the in vitro maturation of the oocytes was done in B199 (Sigma, M4530) supplemented with $10 \% \mathrm{FBS}, 5.0 \mu \mathrm{g} / \mathrm{mL}$ luteinizing hormone and $0.5 \mu \mathrm{g} / \mathrm{mL}$ follicle stimulating hormone (Bioniche Animal Health USA, Inc.), $100 \mu \mathrm{M}$ cysteamine, $0.2 \mu \mathrm{M}$ pyruvate and $50 \mu \mathrm{g} / \mathrm{mL}$ gentamicin. The oocytes were matured in petri dishes (Corning, 430166) in $100 \mu \mathrm{L}$ media droplets under mineral oil for $22 \mathrm{~h}$ in a $\mathrm{CO}_{2}$ incubator (Thermo Fisher Scientific Inc., USA, Forma Series II 3110 ) at $38.5^{\circ} \mathrm{C}$ under an atmosphere of 5\% $\mathrm{CO}_{2}$ in the air (Adona et al., 2016).

\section{In vitro fertilization}

Cryopreserved semen (Brangus) was processed using the density gradient methodology (90\% and $45 \%)$ with Percoll (Annes et al., 2017) and the in vitro fertilization was carried out in a Tyrode's albumin, lactate and pyruvate (TALP) medium supplemented with epinephrine $(250 \mu \mathrm{M})$ penicillamine $(2 \mu \mathrm{M})$, hypotaurine $(1 \mu \mathrm{M})$, and $20 \mu \mathrm{g} / \mathrm{mL}$ heparin (Parrish, 2014). Oocytes and spermatozoa $\left(2 \times 10^{6}\right.$ cells $\left./ \mathrm{mL}\right)$ were cultured for $18 \mathrm{~h}$ in $100 \mu \mathrm{L}$ medium (TALP) drops under mineral oil in petri dishes (Corning, 430166). Embryonic

\section{Cow untreated}

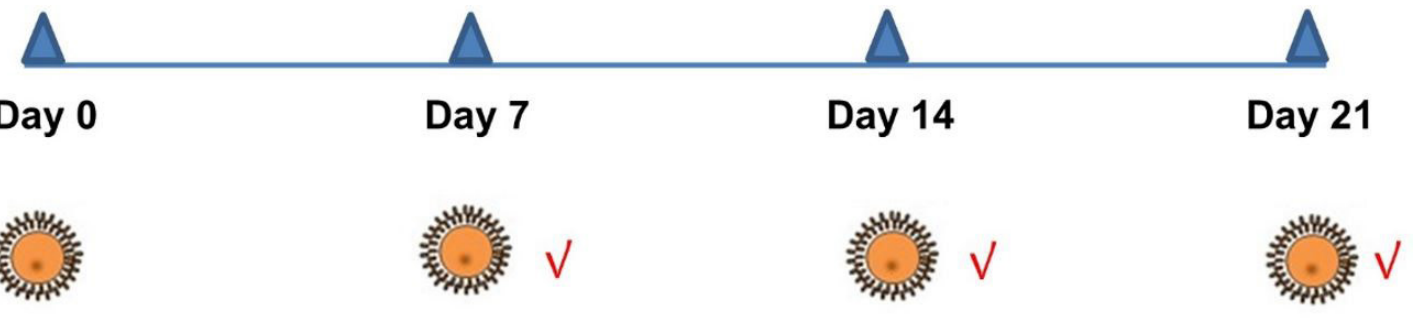

\section{Cow treated}

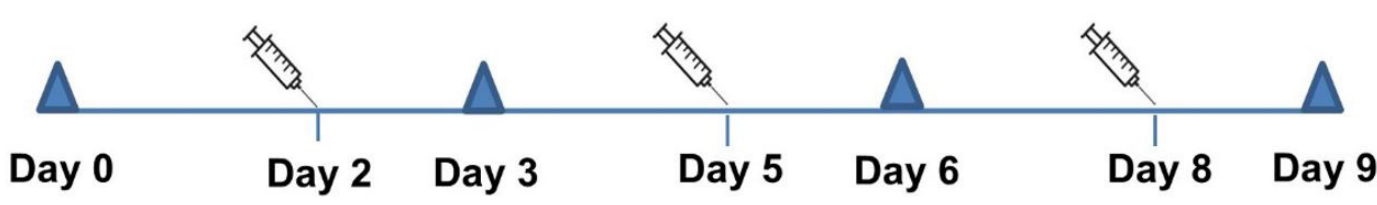

\section{$\triangle$ Ovum Pick Up (OPU) Follicle stimulating hormone (FSH) $\sqrt{ }$ Evaluation}

Figure 1 -Synthetized delineation of the experimental representation. Consecutive OPU protocol for treated (with $200 \mathrm{mg}$ FSH) and untreated Brangus cows.

Adapted figure: Silva et al. (2019). 
development was performed in synthetic oviduct fluid (SOF) medium at $38.5^{\circ} \mathrm{C}$ at a $5 \% \mathrm{CO}_{2}$ atmosphere in the air (Holm et al., 1999; Sovernigo et al., 2017).

\section{Embryo transfer and pregnancy diagnosis}

Recipient cows (Nellore $1 / 2$ and Brown Swiss $1 / 2$ ) were synchronized with intravaginal progesterone implants according to the methodology described by Marques et al. (2015). Embryos (Class I) were transferred by the transcervical method in cows with a corpus luteum of $\geq 18 \mathrm{~mm}$ in diameter. The procedure for assessing pregnancy was by transrectal ultrasonography, 60 days after blastocyst transfer.

\section{Statistical analysis}

Variables for retrieved oocytes, viable oocytes, embryos and pregnancy were analyzed applying the non-parametric chi-square $\left(\mathrm{X}^{2}\right)$ test. Values of $\mathrm{p}<0.05$ were assessed as significant.

\section{Results}

\section{Oocyte recovery}

A total of 223 oocytes were recovered in the control cows and 169 in FSH-treated cows in 3 OPU sessions. The average recovery of oocytes (Figure $2 \mathrm{~A}$ ) is higher $(\mathrm{p}<0.05)$ in control cows $(12.4 \pm 1.8)$ than in cows treated with FSH $(9.4 \pm 1.3)$.

The total number of viable oocytes selected was 116 for control cows, and 106 for FSH-treated cows. There are no significant differences $(\mathrm{p}>0.05)$ in the mean number $(6.4 \pm 1.2$ and $5.9 \pm 1.1)$ or the mean percentage $(52.0 \pm 3.9$ and $62.7 \pm 4.7 \%)$ of viable oocytes between control (without FSH), and FSH-treated cows (Figure 2B, C).

\section{In vitro fertilization}

From the viable oocytes, 48 embryos were produced in vitro from control cows and 44 embryos from cows treated with FSH. The mean percentage of embryos (41.4 \pm 4.8 and $41.5 \pm 4.2 \%$ ) or mean number of embryos per cow $(2.7 \pm 0.8$ and $2.4 \pm 0.6)$ are not significantly different ( $p>0.05$ ) between control (without FSH) and FSH-treated cows (Figure 3A, B).

\section{Pregnancy rate}

Embryos produced in vitro for the control cows (48) and FSH-treated cows (44) were transferred to recipient cows. Twenty-one positive pregnancies were reported for control and 18 for FSH-treated cows. The mean percentage of pregnancies for the transferred embryos (in vitro) (Figure 4$)$ are not significantly different $(\mathrm{p}>0.05)$, between
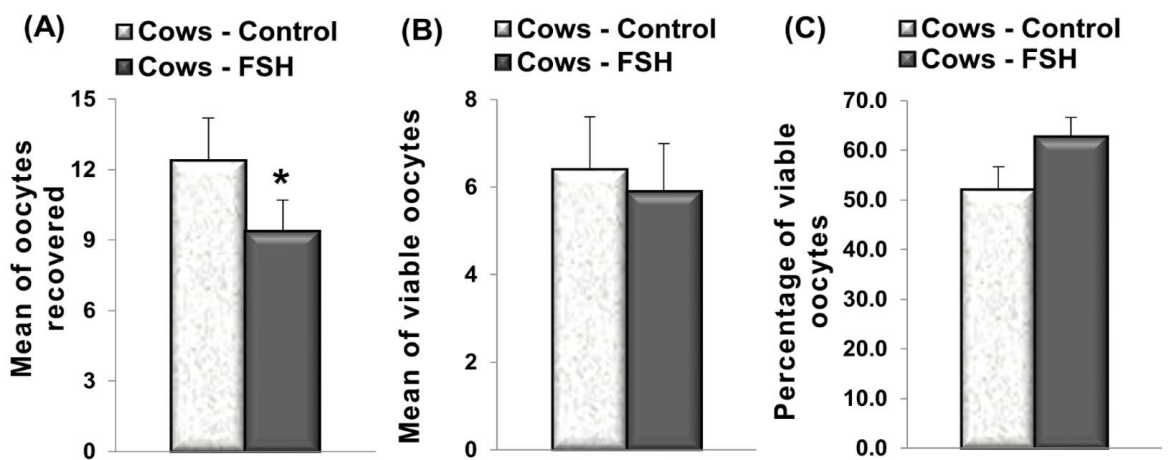

Figure 2 -Mean of total oocytes recovered (A), mean of viable oocytes (B) and percentage of viable oocytes (C) for treated (follicle stimulating hormone - FSH) and untreate3d cows. *Significant difference $(\mathrm{p}<0.05)$.
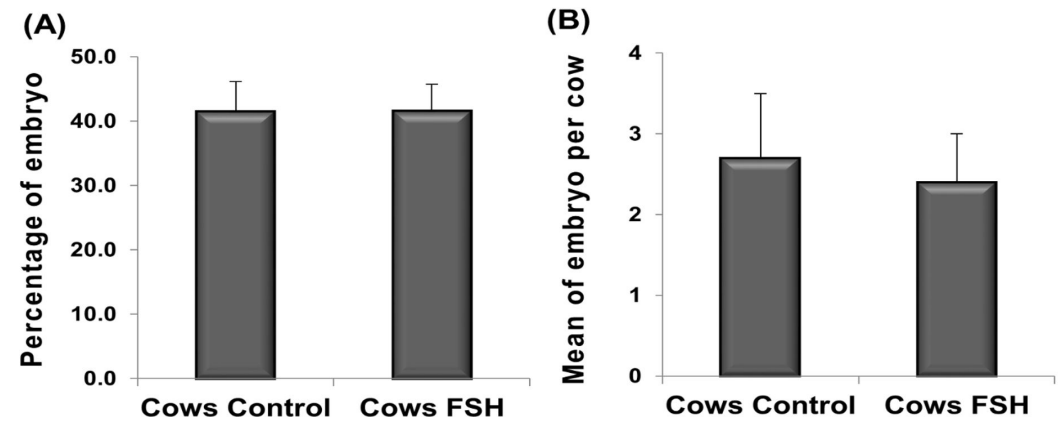

Figure 3 -Mean percentage of blastocysts in vitro production (A) and mean of blastocysts per cow (B) for treated (follicle stimulating hormone - FSH) and untreated cows. 


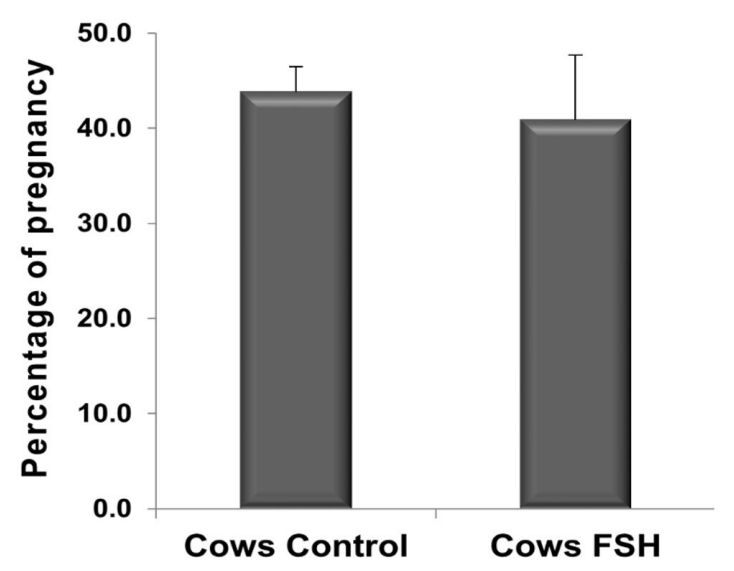

Figure 4-Mean percentage of pregnancies for treated (follicle stimulating hormone - FSH) and untreated cows.

control (without FSH) cows $(43.8 \pm 2.7 \%)$ and FSH-treated cows $(40.9 \pm 6.8 \%)$.

\section{Discussion}

Hormone stimulation with FSH before OPU can be used to increase follicular population and oocyte quality for the in vitro production of embryos (Aller et al., 2010; Goodhand et al., 1999). However, in the present study, the administration of FSH before OPU produced a lower recovery in the total number of oocytes in hormone-treated Brangus cows. This lower rate in total oocyte retrieval in oocyte donor cows treated with FSH may question the overall benefits of superstimulation (Vieira et al., 2014). However, studies show discordant results in the recovery of oocytes with FSH stimulation before OPU. These disagreements between studies may be related to cow breeds, FSH administration protocols, and other causes, such as the age of the cows, genetics, climate and nutrition (Chaubal et al., 2007; Goodhand et al., 2000; Ptak et al., 2003; Silva et al., 2017; Vieira et al., 2014; Vieira et al., 2016).

Physiological differences between bovine breeds (cows) are widely described in the literature. These particularities may have implications for the success of treatments that manipulate follicular development (Bó et al., 2003; Sartori et al., 2016). However, more studies are necessary to evaluate synthetic cows (crosses between Bos indicus and Bos taurus) as donors of oocytes with the application of FSH and OPU, especially for the Brangus breed. However, despite the decrease in the number of oocytes aspirated in the Brangus cows treated with FSH, there is the possibility of several consecutive OPU in close periods (every 3 days), optimizing donor cows and the rates of pregnancy derived from the in vitro fertilization.

Decrease in the number of total oocytes aspirated in FSH-treated Brangus cows did not directly affect the number or rate of viable oocytes among the donors evaluated. However, FSH may have favored uniformity in the number of viable oocytes. According to some studies, FSH is implicated in the follicular development and arrangement of the oocyte cytoplasm determining its quality (Silva et al., 2017; Ginther et al., 2016). This similarity regarding viable oocytes was also observed in other publications that found that the percentage of viable oocytes did not undergo significant changes even in races and protocols of FSH application different from those used in this study (Chaubal et al., 2006; Silva et al., 2017; Vieira et al., 2014). The percentages of viable oocytes in this study, regardless of the treatment of the cows, were superior to that observed in another study that used Brangus cows in the OPU procedure for in vitro embryo production (Guemra et al., 2014). These different results, even within the same breed (Brangus), may be due to the heterogeneity of the synthetic breeds, FSH administration protocols and other factors like age, climate, nutrition, and animal genetics, as previously mentioned (Chaubal et al., 2006; Ptak et al., 2003).

The results of in vitro fertilization are evaluated in terms of the quality of the blastocysts and the pregnancy percentage. Low competence in the in vitro fertilization has been attributed to the lower efficiency of oocytes from growing follicles (anthrax) and submitted to in vitro production of embryos (Merton et al., 2003; Sirard \& Blondin, 1996). However, in spite of the distinctions in the protocols used for obtaining oocytes between cows treated and not with FSH, the percentage of in vitro fertilization was similar for both groups. These results suppose that the treatment of donors did not significantly alter the intrinsic quality of the oocytes, the results of the in vitro fertilization being equivalent to other researches in different races (Silva et al., 2017; Ribeiro et al., 2011). Another cause that plays a crucial function in the in vitro fertilization is oocyte-linked cumulus cells that may negatively affect the outcome of in vitro fertilization (Macaulay et al., 2014; Zhang et al., 1995). However, the methods for classification of viable oocytes for in vitro fertilization in both groups were the same, homogeneous cytoplasm with more than one layer of compact cumulus cells. This similarity in the percentage of embryos is possibly due to the quality of the oocytes submitted to in vitro fertilization, which was similar for both groups. However, FSH has been related to oocyte development capacity, both in vivo and in vitro, in addition to control of somatic cellular activities for follicular growth (Sirard et al., 2007), but a relevant increase in the in vitro fertilization in FSH-treated animals was not observed in this or other studies (Silva et al., 2017; Ribeiro et al., 2011). 
Rizos et al. (2002) mentioned that the quality of blastocysts is compromised by the in vitro culture system and may affect pregnancy rates. However, in this study, the properties of the in vitro culture system were identical between groups, and they did not interfere with the rate of development of the embryos. Furthermore, the different treatments, cows treated or not with FSH, did not significantly influence the percentages of blastocysts and pregnancies. The absence of relevant variation in the pregnancy percentage of embryos produced in vitro for treated or non-FSH-treated cows can be characterized by the equivalent quality of the embryos transferred. The results observed in the present study are similar to those verified in the literature, with distinct breeds and protocols for obtaining oocytes (Guemra et al., 2014; Sanches et al., 2016).

\section{Reference}

Adams GP, Jaiswal R, Singh J, Malhi P. Progress in understanding ovarian follicular dynamics in cattle. Theriogenology. 2008;69(1):72-80. http://dx.doi.org/10.1016/j. theriogenology.2007.09.026. PMid:17980420.

Adona PR, Leal CL, Biase FH, De Bem TH, Mesquita LG, Meirelles FV, Ferraz AL, Furlan LR, Monzani PS, Guemra S. In vitro maturation alters gene expression in bovine oocytes. Zygote. 2016;24(4):624-33. http://dx.doi.org/10.1017/ S0967199415000672. PMid:26885679.

Aller JF, Mucci NC, Kaiser GG, Rios G, Callejas SS, Alberio RH. Transvaginal follicular aspiration and embryo development in superstimulated early postpartum beef cows and subsequent fertility after artificial insemination. Anim Reprod Sci. 2010;119(1-2):1-8. http://dx.doi.org/10.1016/j. anireprosci.2009.11.009. PMid:20036087.

Annes K, Soares CA, Lima CBD, Milazzotto MP. Effective individual culture system for in vitro production of bovine embryos. Braz J Vet Res Anim Sci. 2017;54(3):209-14. http:// dx.doi.org/10.11606/issn.1678-4456.bjvras.2017.107721.

Baruselli PS, Gimenes LU, Sales JNS. Reproductive physiology of Bos taurus and Bos indicus females. Rev Bras Reprod Anim. 2007;31(2):205-11.

Bó GA, Baruselli P, Martinez M. Pattern and manipulation of follicular development in Bos indicus cattle. Anim Reprod Sci. 2003;78(3-4):307-26. http://dx.doi.org/10.1016/S03784320(03)00097-6. PMid:12818651.
In conclusion, single dose FSH protocol in Brangus donors did not improve oocyte recovery (in general terms), in vitro fertilization, and pregnancy percentage. However, there is the possibility of several consecutive OPU in close periods, optimizing donor cows and the rates of pregnancy derived from the in vitro fertilization.

\section{Conflicts of Interest}

The authors declare no conflicts of interest.

\section{Ethics Statement}

The use of cows for the experiment was submitted and approved by the Unopar Ethics Committee (no 004/17) following the guidelines of Animal Experimentation.

Burrow HM. Genetic aspects of cattle adaptation in the tropics. In: Garrick DJ, Ruvinsky A. The genetics of cattle. 2nd ed. London: CAB International; 2015. p. 33.

Chaubal SA, Ferre LB, Molina JA, Faber DC, Bols PE, Rezamand P, Tian X, Yang X. Hormonal treatments for increasing the oocyte and embryo production in an OPU-IVP system. Theriogenology. 2007;67(4):719-28. http://dx.doi. org/10.1016/j.theriogenology.2006.07.022. PMid:17140652.

Chaubal SA, Molina JA, Ohlrichs CL, Ferre LB, Faber DC, Bols PE, Riesen JW, Tian X, Yang X. Comparison of different transvaginal ovum pick-up protocols to optimise oocyte retrieval and embryo production over a 10 -week period in cows. Theriogenology. 2006;65(8):1631-48. http://dx.doi. org/10.1016/j.theriogenology.2005.07.020. PMid:16243385.

Gimenes LU, Ferraz ML, Fantinato-Neto P, Chiaratti MR, Mesquita LG, Sá MF Fo, Meirelles FV, Trinca LA, Rennó FP, Watanabe YF, Baruselli PS. The interval between the emergence of pharmacologically synchronized ovarian follicular waves and ovum pickup does not significantly affect in vitro embryo production in Bos indicus, Bos taurus, and Bubalus bubalis. Theriogenology. 2015;83(3):385-93. http://dx.doi.org/10.1016/j.theriogenology.2014.09.030. PMid:25447149.

Ginther OJ, Siddiqui MA, Baldrighi JM, Araujo ER. An intraovarian mechanism that enhances the effect of an FSH surge on recovery of subordinate follicles in heifers. Domest Anim Endocrinol. 2017;59:67-74. http://dx.doi. org/10.1016/j.domaniend.2016.10.003. PMid:28002761. 
Ginther OJ, Siddiqui MA, Baldrighi JM, WolfCA, Castro T. Temporality of two-way functional coupling between FSH and follicles in heifers. Theriogenology. 2016;86(7):164553. http://dx.doi.org/10.1016/j.theriogenology.2015.10.006. PMid:27520291.

Goodhand KL, Staines ME, Hutchinson JS, Broadbent PJ. In vivo oocyte recovery and in vitro embryo production from bovine oocyte donors treated with progestagen, oestradiol and FSH. Anim Reprod Sci. 2000;63(3-4):145-58. http:// dx.doi.org/10.1016/S0378-4320(00)00186-X. PMid:10989225.

Goodhand KL, Watt RG, Staines ME, Hutchinson JS, Broadbent PJ. In vivo oocyte recovery and in vitro embryo production from bovine donors aspirated at different frequencies or following FSH treatment. Theriogenology. 1999;51(5):951-61. http://dx.doi.org/10.1016/S0093691X(99)00041-2. PMid:10729017.

Guemra S, Santo ES, Zanin R, Monzani PS, Sovernigo TC, Ohashi OM, Leal CLV, Adona PR. Effect of temporary meiosis block during prematuration of bovine cumulus-oocyte complexes on pregnancy rates in a commercial setting for in vitro embryo production. Theriogenology. 2014;81(7):9827. http://dx.doi.org/10.1016/j.theriogenology.2014.01.026. PMid:24576716.

Gupta PS, Folger JK, Rajput SK, Lv L, Yao J, Ireland JJ, Smith GW. Regulation and regulatory role of WNT signaling in potentiating FSH action during bovine dominant follicle selection. PLoS One. 2014;9(6):e100201. http://dx.doi. org/10.1371/journal.pone.0100201. PMid:24936794.

Holm P, Booth PJ, Schmidt MH, Greve T, Callesen H. High bovine blastocyst development in a static In vitro production system using SOFaa medium supplemented with sodium citrate and myo-inositol with or without serumproteins. Theriogenology. 1999;52(4):683-700. http://dx.doi. org/10.1016/S0093-691X(99)00162-4. PMid:10734366.

Kelly P, Duffy P, Roche JF, Boland MP. Superovulation In cattle: effect of fsh type and method of administration on follicular growth, ovulatory response and endocrine patterns. Anim Reprod Sci. 1997;46(1-2):1-14. http://dx.doi. org/10.1016/S0378-4320(96)01589-8. PMid:9231242.

Lamy E, Van Harten S, Sales-Baptista E, Guerra MMM, De Almeida AM. Factors influencing livestock productivity environmental estress and amelioration in livestock production. Springer; 2012.

Macaulay AD, Gilbert I, Caballero J, Barreto R, Fournier E, Tossou P, Sirard MA, Clarke HJ, Khandjian ÉW, Richard
FJ, Hyttel P, Robert C. The gametic synapse: RNA transfer to the bovine oocyte. Biol Reprod. 2014;91(4):1-12. http:// dx.doi.org/10.1095/biolreprod.114.119867. PMid:25143353.

Marques MO, Morotti F, Silva CB, Ribeiro MR Jr, Silva RC, Baruselli PS, Seneda MM. Influence of category-heifers, primiparous and multiparous lactating cows--in a largescale resynchronization fixed-time artificial insemination program. J Vet Sci. 2015;16(3):367-71. http://dx.doi. org/10.4142/jvs.2015.16.3.367. PMid:25797292.

Merton J, De Roos A, Mullaart E, De Ruigh L, Kaal L, Vos P, Dieleman S. Factors affecting oocyte quality and quantity in commercial application of embryo technologies in the cattle breeding industry. Theriogenology. 2003;59(2):65174. http://dx.doi.org/10.1016/S0093-691X(02)01246-3. PMid:12499010.

Mihm M, Good TE, Ireland JL, Ireland JJ, Knight PG, Roche JF. Decline in serum follicle-stimulating hormone concentrations alters key intrafollicular growth factors involved in selection of the dominant follicle in heifers. Biol Reprod. 1997;57(6):1328-37. http://dx.doi.org/10.1095/ biolreprod57.6.1328. PMid:9408237.

Monteiro FM, Batista EOS, Vieira LM, Bayeux BM, Accorsi M, Campanholi SP, Dias EAR, Souza AH, Baruselli PS. Beef donor cows with high number of retrieved COC produce more in vitro embryos compared with cows with low number of COC after repeated ovum pick-up sessions. Theriogenology. 2017;90:54-8. http://dx.doi.org/10.1016/j. theriogenology.2016.11.002. PMid:28166988.

Nasser LF, Adams G, Bo G, Mapletoft R. Ovarian superstimulatory response relative to follicular wave emergence in heifers. Theriogenology. 1993;40(4):71324. http://dx.doi.org/10.1016/0093-691X(93)90207-L. PMid:16727353.

Parrish JJ. Bovine in vitro fertilization: in vitro oocyte maturation and sperm capacitation with heparin. Theriogenology. 2014;81(1):67-73. http://dx.doi.org/10.1016/j. theriogenology.2013.08.005. PMid:24274411.

Perry G. Statistics of embryo collection and transfer in domestic farm animals. Embryo Transfer Newsletter. 2014;32:14-26.

Pontes JH, Silva KC, Basso AC, Rigo AG, Ferreira CR, Santos GM, Sanches BV, Porcionato JP, Vieira PH, Faifer FS, Sterza FA, Schenk JL, Seneda MM. Large-Scale in vitro embryo production and pregnancy rates from Bos taurus, Bos indicus, and indicus-taurus dairy cows using sexed 
sperm. Theriogenology. 2010;74(8):1349-55. http://dx.doi. org/10.1016/j.theriogenology.2010.06.004. PMid:20708245.

Ptak G, Tischner M, Bernabo N, Loi P. Donor-dependent developmental competence of oocytes from lambs subjected to repeated hormonal stimulation. Biol Reprod. 2003;69(1):27885. http://dx.doi.org/10.1095/biolreprod.102.011312. PMid:12606346.

Ribeiro LVP, Rigolon LP, Cavalieri FLB, Seko MB, Martinez AC, Ribeiro MG, Martins RR, Ávila MR, De Conti JB. Oocyte recovery and in vitro production from cows stimulated with either FSH or eCG. Arch Zootec. 2011;60(232):10219. http://dx.doi.org/10.4321/S0004-05922011000400018.

Rizos D, Ward F, Duffy P, Boland MP, Lonergan P. Consequences of bovine oocyte maturation, fertilization or early embryo development in vitro versus in vivo: implications for blastocyst yield and blastocyst quality. Mol Reprod Dev. 2002;61(2):234-48. http://dx.doi.org/10.1002/ mrd.1153. PMid:11803560.

Sanches BV, Lunardelli PA, Tannura JH, Cardoso BL, Pereira MH, Gaitkoski D, Basso AC, Arnold DR, Seneda MM. A new direct transfer protocol for cryopreserved IVF embryos. Theriogenology. 2016;85(6):1147-51. http://dx.doi. org/10.1016/j.theriogenology.2015.11.029. PMid:26739533.

Sartori R, Monteiro P Jr, Wiltbank M. Endocrine and metabolic differences between Bos taurus and Bos indicus cows and implications for reproductive management. Anim Reprod. 2016;13(3):168-81. http://dx.doi.org/10.21451/19843143-AR868.

Silva BLM, Adona PR, Guemra S, Monzani PS, Miranda MS. Ovum pick up: cows treated with single doses of follicle stimulating hormone. J Agric Sci. 2019;11(10):231-9. http:// dx.doi.org/10.5539/jas.v11n10p231.

Silva JCB, Ferreira RM, Maturana M Fo, Naves JR, Santin T, Pugliesi G, Madureira EH. Use of FSH in two different regimens for ovarian superstimulation prior to ovum pick up and in vitro embryo production in Holstein cows. Theriogenology. 2017;90:65-73. http://dx.doi.org/10.1016/j. theriogenology.2016.11.016. PMid:28166990.
Sirard M, Blondin P. Oocyte maturation and IVF in cattle. Anim Reprod Sci. 1996;42(1):417-26. http://dx.doi. org/10.1016/0378-4320(96)01518-7.

Sirard MA, Desrosier S, Assidi M. In vivo and in vitro effects of FSH on oocyte maturation and developmental competence. Theriogenology. 2007;68(1, Suppl. 1):71-6. http://dx.doi.org/10.1016/j.theriogenology.2007.05.053. PMid:17588652.

Sovernigo TC, Adona PR, Monzani PS, Guemra S, Barros F, Lopes FG, Leal C. Effects of supplementation of medium with different antioxidants during in vitro maturation of bovine oocytes on subsequent embryo production. Reprod Domest Anim. 2017;52(4):561-9. http://dx.doi.org/10.1111/ rda.12946. PMid:28295710.

Vieira LM, Rodrigues CA, Castro A No, Guerreiro BM, Silveira CR, Moreira RJ, Sá MF Fo, Bó GA, Mapletoft RJ, Baruselli PS. Superstimulation prior to the ovum pick-up to improve in vitro embryo production in lactating and nonlactating Holstein cows. Theriogenology. 2014;82(2):318-24. http://dx.doi.org/10.1016/j.theriogenology.2014.04.013. PMid:24839924.

Vieira LM, Rodrigues CA, Castro A No, Guerreiro BM, Silveira CRA, Freitas BG, Bragança LGM, Marques KNG, Sá MF Fo, Bó GA, Mapletoft RJ, Baruselli PS. Efficacy of a single intramuscular injection of porcine FSH in hyaluronan prior to ovum pick-up in Holstein cattle. Theriogenology. 2016;85(5):877-86. http://dx.doi. org/10.1016/j.theriogenology.2015.10.036. PMid:26639640.

Zhang L, Jiang S, Wozniak PJ, Yang X, Godke RA. Cumulus cell function during bovine oocyte maturation, fertilization, and embryo development in vitro. Mol Reprod Dev. 1995;40(3):338-44. http://dx.doi.org/10.1002/mrd.1080400310. PMid:7772344.

Financial Support: Pythagoras Unopar University.

Authors Contributions: All authors contributed considerably to: project preparation, experimental execution, writing conception. 